\title{
EVALUASI PROGRAM PENDAMPINGAN KEPALA SEKOLAH OLEH PENGAWAS SEKOLAH BAGI PENINGKATAN KUALITAS PEMBELAJARAN DI PALANGKARAYA
}

\author{
(Evaluation Mentoring Program Principal For The Supervision Of Schools Improving The Quality Of \\ Learning In Palangkaraya)
}

\section{IIN NURBUDIYANI}

\author{
Program Studi Pendidikan Ekonomi Fakultas Keguruan dan IImu Pendidikan \\ Universitas Muhammadiyah Palangkaraya \\ JI. RTA Milono Km. 1,5 Palangka Raya, Kalimantan Tengah. 73111 \\ e-mail: iinnurbudiyani11@gmail.com
}

\begin{abstract}
This study aims to evaluation of training programs mentoring principals by school supervisors to improving the quality of learning in Palangkaraya. This study included evaluation using descriptive analytic method. Instrument data collection using questionnaires, tests, review of documents, and focus group discussion. This research target is 8 supervisors who each cultivate 3-5 schools that amounted to 35 schools. Evaluation model used in this study are four levels of Kirkpatrick, reaction, learning, behavior and results. It is concluded that (1) This training has relevance level of $85.14 \%$ (good categories), (2) The training has the effectiveness rate of $92.57 \%$ (excellent categories), and the effect size of 2.0832 category great because of greater than 0.8, (3) training is a positive impact on: (a) implementation of the management of the school curriculum with an average score of 84.13 (good categories), (b) implementation of lesson preparation, implementation of learning and learning outcomes with an average score of 82.91 (good categories), so the overall impact with an average of 83.52 (good categories).
\end{abstract}

Keywords: Evaluation, relevance, effectiveness, quality of learning

\begin{abstract}
ABSTRAK
Adapun yang menjadi tujuan dari penelitian ini adalah untuk mengevaluasi program pelatihan pendampingan kepala sekolah oleh pengawas sekolah bagi peningkatan kualitas pembelajaran di Palangkaraya. Penelitian ini termasuk evaluasi dengan menggunakan metode deskriptif analitik. Instrumen pengumpulan datanya menggunakan kuesioner, tes, telaah dokumen, dan focus group discussion. Sasaran penelitian ini adalah 8 pengawas yang masing-masing membina 3-5 sekolah sehingga berjumlah 35 sekolah. Model evaluasi yang digunakan dalam penelitian ini adalah four level dari Kirkpatrick, yaitu reaction, learning, behavior and results. Kesimpulan penelitian ini adalah: (1) Pelatihan ini memiliki tingkat relevansi sebesar $85,14 \%$ (kategori baik), (2) Pelatihan ini memiliki tingkat efektivitas sebesar 92,57\% (kategori baik sekali), dan effect size sebesar 2,0832 termasuk kategori besar karena lebih besar dari 0,8, (3) Pelatihan ini berdampak positif terhadap: (a) Implementasi pengelolaan kurikulum sekolah dengan skor rata-rata 84,13 (kategori baik), (b) Implementasi persiapan pembelajaran, pelaksanaan pembelajaran dan hasil belajar dengan skor rata-rata 82,91 (kategori baik), sehingga dampak secara keseluruhan dengan rata-rata sebesar 83,52 (kategori baik).
\end{abstract}

Kata Kunci : Evaluasi, Relevansi, Efektivitas dan kualitas pembelajaran 


\section{PENDAHULUAN}

Perkembangan dunia pendidikan dan perubahan sosial budaya yang terjadi secara intens dalam skala masif membawa dampak besar terhadap perubahan cara pandang (shifting paradigm) terhadap dunia pendidikan khususnya dan aspek lain pada umumnya (Said, 2014). Perubahan dimaksud memiliki pengaruh yang sangat luas terhadap kebijakan Pemerintah terutama dalam menyikapi peningkatan kualitas sumber daya manusia (SDM) yang qualified dan profesional yang selaras dengan tuntutan global market share (Cunningham, 1996), dan guna menopang pencapaian tujuan pembangunan nasional.

Dalam upaya peningkatan kualitas SDM yang qualified dan profesional, pendidikan dan pelatihan memiliki peran yang sangat penting. Melalui pendidikan dan pelatihan akan mampu meningkatkan kualitas serta potensi yang dimiliki oleh seseorang dalam melakukan sesuatu sehingga dengan potensi tersebut akan menumbuhkan rasa percaya diri (Alwan, 2012). Sejalan dengan hal tersebut, Kementerian Pendidikan dan Kebudayaan menyelenggarakan berbagai program pelatihan dalam peningkatan kualitas SDM. Diantaranya adalah pelatihan guru, kepala sekolah, pengawas sekolah dalam Program BERMUTU (Better Education through Reformed Management and Universal Teacher Upgraiding), Pelatihan dalam Program Pendampingan Kepala Sekolah oleh Pengawas Sekolah/Madrasah (PPKS-PS/M).

Sayangnya program pelatihan terkadang tidak diikuti dengan evaluasi. Pada kebanyakan organisasi, sepanjang peserta diklat merasa senang, maka pelatihan dianggap berhasil.
Padahal ukuran seperti itu belum tentu menjamin tercapainya tujuan suatu pelatihan. Sementara menurut Febriati (2015:6) program pelatihan pegawai sering menghadapi masalah klasik, yakni: (a) materi diklat tidak relevan dengan kebutuhan pegawai karena tidak diawali dengan analisis kebutuhan, (b) pelatihan tidak dikaitkan dengan sistem kompensasi dan karier pegawai, sehingga pegawai kurang termotivasi untuk melakukan perubahan sikap dan perilaku setelah mengikuti pelatihan.

Padahal bagi organisasi, program pelatihan merupakan suatu investasi, yang pada akhirnya meningkatkan kinerja organisasi secara keseluruhan, dan program pelatihan biasanya menghabiskan dana yang tidak kecil jumlahnya. Noe (1998:62) mengatakan bahwa untuk meyakinkan bahwa program pelatihan yang diselenggarakan tidak sia-sia, maka perlu dilakukan evaluasi program pelatihan. Secara khusus, Kirkpatrick (1998:36) mengemukakan alasan mengapa suatu pelatihan perlu dievaluasi. Pertama, evaluasi dilakukan untuk mengetahui apakah pelatihan dapat memberikan kontribusi pada pencapaian tujuan organisasi atau tidak. Kedua, pelatihan perlu dievaluasi untuk memutuskan apakah program pelatihan tersebut perlu dilanjutkan atau tidak. Ketiga, adalah evaluasi pelatihan dilakukan untuk mendapatkan informasi mengenai bagaimana meningkatkan dan mengembangkan program pelatihan yang akan datang. Dengan demikian, penyelenggaraan pelatihan tidak hanya sekadar penyelenggaraan saja tetapi dengan jutaan dana yang telah dikeluarkan, pelatihan dapat memberikan manfaat bagi individu yang mengikutinya juga bagi kinerja organisasi. Oleh karena itu, materi pelatihan 
haruslah relevan dengan kebutuhan dan pelaksanaannya haruslah efektif.

Relevansi adalah kesesuaian isi pelatihan dengan pekerjaan pokok peserta pelatihan, selain itu juga apakah pelatihan yang dilakukan sesuai dengan kemampuan peserta untuk menerapkannya dalam pekerjaan. Relevansi dapat dipandang pula sebagai suatu sifat yang terdapat pada pelaksanaan diklat yang dapat memvasilitasi peserta diklat dalam memecahkan masalah/memenuhi kebutuhan kerjanya. Jadi, diklat yang dikuti dinilai relevan bila diklat tersebut memiliki materi tatar yang sama atau berhubungan dengan kebutuhan pelaksanaan kerja peserta diklat itu sendiri.

Sedang pelatihan dikatakan efektif jika hasil dari pelatihan tersebut dapat mencapai tujuan organisasi, meningkatkan kemampuan sumber daya, memuaskan konsumen atau meningkatkan proses internal (Kaswan, 2011:15). Hal senada juga dikemukakan oleh Musadad (2012:93) bahwa efektivitas merupakan unsur pokok untuk mencapai tujuan atau sasaran yang telah ditentukan di dalam setiap organisasi. Kegiatan ataupun program disebut efektif apabila tercapai tujuan ataupun sasaran seperti yang telah ditentukan. Dengan demikian dapat disintesiskan bahwa efektivitas pelatihan adalah ukuran yang menyatakan seberapa jauh tujuan, sasaran dari pelatihan yang telah ditentukan sebelumnya dapat dicapai (secara kualitas, maupun kuantitas).

Untuk mengukur relevansi dan efektivitas pelatihan digunakan model evaluasi four level dari Kirkpatrick, yaitu reaction, learning, behavior dan results. Level reaction, mengevaluasi reaksi peserta training atau mengukur kepuasan peserta terhadap pelaksanaan pelatihan. Program training dianggap efektif apabila proses training dirasa menyenangkan dan memuaskan bagi peserta training, sehingga mereka tertarik dan termotivasi untuk belajar dan berlatih. Sebaliknya apabila peserta tidak merasa puas terhadap proses training yang diikutinya mereka tidak akan termotivasi untuk mengikuti training.

Level learning, mengukur hasil belajar. Peserta training dikatakan telah belajar apabila pada dirinya telah mengalami perubahan sikap, perbaikan pengetahuan maupun peningkatan keterampilan. Oleh karena itu untuk mengukur efektivitas program training maka ketiga aspek tersebut perlu untuk diukur. Tanpa adanya perubahan sikap, peningkatan pengetahuan atau keterampilan pada peserta training, maka program dapat dikatakan gagal. Menurut Kirkpatrick (1998:40), untuk menilai hasil belajar dapat dilakukan dengan membandingkan hasil pre-test dengan post-test, baik tes tertulis ataupun tes kinerja (performancetest).

Level behavior mengukur perilaku sebelum dan sesudah mengikuti training dengan mengadakan survei atau interview dengan pelatih, atasan maupun bawahan peserta training setelah mereka kembali ke tempat kerja. Evaluasi behavior dapat difokuskan pada perubahan tingkah laku peserta setelah selesai mengikuti pelatihan. Sehingga penilaian tingkah laku ini lebih bersifat eksternal. Karena yang dinilai adalah perubahan perilaku setelah mengikuti kegiatan pembelajaran dan kembali ke lingkungan mereka maka evaluasi level ke-3 ini dapat disebut sebagai evaluasi terhadap outcomes dari kegiatan pelatihan. 
Level result fokus pada hasil akhir (final result) yang terjadi karena peserta pelatihan telah mengikuti suatu program pelatihan. Beberapa program mempunyai tujuan untuk meningkatkan hasil yang lebih baik. Jadi, result evaluation adalah evaluasi terhadap impact (pengaruh) program. Hubungan antarlevel model evaluasi Kirkpatrick secara visual tampak pada tabel 1.

\section{METODE PENELITIAN}

Penelitian ini adalah penelitian evaluatif, yaitu mengevaluasi relevansi dan efektivitas Program Pelatihan Pendampingan Kepala Sekolah/Madrasah oleh Pengawas Sekolah/Madrasah di Kota Palangka Raya, Provinsi Kalimantan Tengah. Metode penelitian yang digunakan dalam penelitian ini adalah metode deskriptif analitik. Teknik pengumpulan datanya menggunakan kuesioner, tes, telaah dokumen, dan focus group discussion. Data-data yang telah dikumpulkan, disusun, dan diklasifikasikan kemudian dianalisis berdasarkan teori-teori yang berhubungan dengan masalahmasalah yang diteliti untuk menghasilkan kesimpulan dan saran. kisi-kisi instrumen penelitian ini seperti tampak dalam tabel 2.

Teknik analisis data (sesuai dengan level) dilakukan dengan tahapan sebagai berikut:

1. Analisis data reaction yang dikumpulkan melalui kuesioner dianalisis dengan langkahlangkah sebagai berikut:

a. Menginput jawaban kuesioner yang diisi peserta (skala 1-5) dengan bantuan Microsoft Excel untuk melihat seberapa tingkat relevansi dan efektivitas pelatihan. b. Mengukur tingkat relevansi dan efektivitas pelatihan ke dalam 5 kategori, berdasarkan tabel 3

2. Analisis data learning yang berupa hasil belajar aspek pengetahuan yang diperoleh melalui tes dianalisis dengan langkah-langkah sebagai berikut:

a. Memberi skor pada jawaban peserta, benar skor 1 , salah skor 0 .

b. Selanjutnya data dianalisis dengan menggunakan T-Test (dengan bantuan Microsoft Excel) untuk melihat apakah terdapat peningkatan yang berarti secara statistik pada pengetahuan akibat pelatihan.

c. Untuk mengukur dampak (d), yakni perubahan dari keluaran yang didapatkan sebagai dampak dari pelatihan digunakan metode Cohen (1988), yaitu dengan membagi hasil pembelajaran dengan standar deviasi dari pre-test.

$d=\frac{\text { mean post-tes }- \text { mean pre-test }}{\text { standar deviasi pre-test }}$

d. Selanjutnya untuk melihat besarnya dampak (effect size) digunakan aturan dari Cohen (1988) dengan kriteria seperti berikut:

$$
\begin{array}{ll}
\text { Dampak Kecil } & : 0.20-0.49 \\
\text { Dampak Sedang } & : 0.50-0.79 \\
\text { Dampak Besar : > 0.8 } &
\end{array}
$$

3. Analisis data learning aspek keterampilan yang dikumpulkan melalui studi dokumen naskah KTSP dan RPP dianalisis dengan langkah sebagai berikut:

a. Pemberian skor. Indikator dari setiap komponen yang terpenuhi dengan benar, lengkap diberi skor 1 (satu), dan jika tidak 
ada/tidak lengkap/salah diberi skor 0 (nol).

b. Selanjutnya data dianalisis untuk menentukan nilai penguasaan kompetensi (PK) dengan menggunakan rumus:

$$
P K=\frac{\sum X i}{n .1} \times 100 \%
$$

Keterangan:

$\mathrm{X}_{1}=$ skor yang diperoleh dari setiap indikator

$\mathrm{n}$ = jumlah indikator

1 = skor benar, lengkap

c. Nilai penguasaan kompetensi dalam bentuk persentase selanjutnya dikonversi menjadi bentuk kategori berdasarkan Pasal 15 ayat (2) Permeneg PAN dan RB No 16 tahun 1999 tentang Jabatan Fungsional Guru dan Angka Kreditnya. Berdasarkan ketentuan tersebut, kompetensi guru diklasifikasikan ke dalam 5 kategori, berdasarkan tabel 4

4. Analisis data behavior yang dikumpulkan menggunakan daftar ceklis dianalisis dengan langkah-langkah sebagai berikut:

a. Indikator dari setiap komponen yang ada buktinya, benar, dan lengkap diberi skor 1, dan jika tidak ada, tidak lengkap, salah diberi skor 0 .

b. Selanjutnya data dianalisis untuk menentukan nilai behavior dengan menggunakan rumus:

$$
P K=\frac{\sum X i}{n .1} \times 100 \%
$$

Keterangan:

$\mathrm{X}_{1}=$ skor yang diperoleh dari setiap indikator

$\mathrm{n}=$ jumlah indikator

1 = skor benar, lengkap

c. Nilai penerapan hasil Diklat di tempat tugas dalam bentuk persentase selanjutnya dikonversi ke dalam 5

kategori, berdasarkan tabel 5

5. Analisis data results (dampak program pelatihan) yang dikumpulkan melalui $F G D$ (data kualitatif) dianalisis dengan tahapan sebagai berikut.

a) Mentranskrip rekaman FGD dan wawancara.

b) Membaca semua transkrip sesuai paparan/jawaban yang diberikan peserta.

c) Review jawaban peserta dengan memberikan simbol pada setiap jawaban peserta.

d) Identifikasi dan temukan tema-tema yang sama.

e) Review kembali tema dan tentukan mana yang paling banyak atau sering muncul.

f) Data dianalisis menjadi "pattern".

g) Setelah pattern di dapat, review kembali tema untuk melihat apa yang disampaikan.

h) Diinterpretasikan menjadi satu kesatuan dengan data utamanya untuk memberikan informasi terhadap hasil pelatihan yang telah dilaksanakan.

\section{HASIL DAN PEMBAHASAN}

\section{Level Reaction (Relevansi dan Efektivitas)}

Hasil analisis data level reaction (aspek relevansi dan efektivitas) diperoleh data pada tabel 6.

Berdasarkan data pada tebel 6 , tampak bahwa pelatihan PPKSPS/M memiliki tingkat relevansi sebesar $85,14 \%$ (masuk dalam kategori baik), dan peserta menilai bahwa efektivitas pelatihan adalah $92,57 \%$ (termasuk dalam kategori baik sekali). 
Level Learning (Perubahan Knowledge \& Skill Partisipan)

Data hasil analisis pretest dan posttest pada in learning 1 dapat dipaparkan dalam tabel 7. Menunjukkan bahwa hasil t-test sebesar 3,62583E-13. Hasil ini dapat dimaknai dengan tingkat keyakinan 95\% telah terjadi pembelajaran dengan dampak pembelajaran dengan kategori besar yang ditunjukkan oleh effect size sebesar 2,08. Menurut Cohen (1988) angka ini termasuk kategori besar karena lebih besar dari 0,8.
Tabel 8 menunjukkan bahwa hasil t-test dari nilai pre-test dan post-test in 2 sebesar 7,8021E-11. Hal ini dapat dikatakan bahwa dengan tingkat keyakinan $95 \%$ dampak pembelajaran di dalam kelas masuk kategori besar yang ditunjukkan oleh effect size sebesar 2,0864. Menurut Cohen (1988) angka ini termasuk kategori besar karena lebih besar dari 0,8 . Namun jika diukur berdasarkan jenis kelamin, nilai $t$-test dari pretest dan post-test kedua kelompok, yaitu laki-laki dan perempuan, ternyata pada kelompok laki-laki lebih besar dari pada kelompok perempuan. Laki-laki $=2,482$, sedang perempuan $=1,5066$.

Tabel 1. Empat Level Evaluasi Pelatihan Kirkpatrick

\begin{tabular}{|c|c|c|}
\hline Level Evaluasi & Area & Fokus \\
\hline Level 1. Reaction & & Kepuasan partisipan terhadap proses pelatihan \\
\hline Level 2. Learning & Within the Training & $\begin{array}{l}\text { Perubahan knowledge, skill \& attitude } \\
\text { partisipan }\end{array}$ \\
\hline $\begin{array}{l}\text { Level 3. Behaviour } \\
\text { (Jobapplication) }\end{array}$ & $\begin{array}{l}\text { At the Job after } \\
\text { Training }\end{array}$ & $\begin{array}{l}\text { Penerapan apa yang telah dipelajari ke dalam } \\
\text { kerja }\end{array}$ \\
\hline $\begin{array}{l}\text { Level 4. Results } \\
\text { (Observable) }\end{array}$ & $\begin{array}{l}\text { Organizational } \\
\text { Effectiveness }\end{array}$ & $\begin{array}{l}\text { Apakah tercapai hasil yang sesuai dengan } \\
\text { yang diinginkan }\end{array}$ \\
\hline
\end{tabular}

Tabel 2. Kisi-Kisi Instrumen Penelitian

\begin{tabular}{|c|c|c|c|}
\hline LEVEL & ASPEK & & INDIKATOR \\
\hline \multirow{3}{*}{ Reaction } & Relevansi & $\begin{array}{l}1 . \\
2 .\end{array}$ & $\begin{array}{l}\text { Kesesuaian isi pelatihan ini dengan pekerjaan } \\
\text { Kemampuan peserta untuk menerapkannya pada pekerjaan }\end{array}$ \\
\hline & Efektivitas & $\begin{array}{l}1 . \\
2 . \\
3 . \\
4 .\end{array}$ & $\begin{array}{l}\text { Penguasaan materi para pelatih } \\
\text { Kualitas materi yang disediakan } \\
\text { Metode pelatihan yang digunakan } \\
\text { Penyelenggaraan pelatihan secara keseluruhan }\end{array}$ \\
\hline & Pengetahuan & $\begin{array}{l}\text { 1) } \\
\text { 2) } \\
\text { 3) } \\
\text { 4) } \\
\text { 5) } \\
\text { 6) } \\
\text { 7) } \\
\text { 8) } \\
\text { 9) } \\
\text { 10) } \\
\text { 11) } \\
\text { 12) }\end{array}$ & $\begin{array}{l}\text { Menyebutkan komponen kurikulum } 2013 \\
\text { Menjelaskan mekanisme penyusunan dan pengelolaan kurikulum } \\
\text { Menjelaskan teknik pembuatan visi } \\
\text { Menjelaskan teknik pembuatan misi } \\
\text { Menjelaskan prinsip pengembangan muatanLokal } \\
\text { Menyusun pedoman kegiatan ekstrakurikuler } \\
\text { Menganalisis RPP } \\
\text { Mengembangkan RPP } \\
\text { Menyusun kegiatan pembelajaran dengan strategi yang tepat } \\
\text { Menentukan metode yang sesuai dengan tujuan pembelajaran } \\
\text { Memilih bentuk penilaian yang tepat } \\
\text { Menyusun instrumen/soal penilaian autentik }\end{array}$ \\
\hline
\end{tabular}




\begin{tabular}{|c|c|c|}
\hline & $\begin{array}{l}\text { Keterampilan } \\
\text { a. Menyusun/ } \\
\text { menyempurnakan } \\
\text { dokumen I KTSP }\end{array}$ & $\begin{array}{l}\text { Kelengkapan Dokumen I KTSP } \\
\text { 13) } \text { Misi-misi satuan pendidikan } \\
\text { 14) Tujuan satuan pendidikan } \\
\text { 15) Struktur dan muatan kurikulum } \\
\text { 16) Program muatan lokal } \\
\text { 17) } \text { Kegiatan pengembangan diri } \\
\text { 18) } \text { Program pembiasaan, keteladanan } \\
\text { 19) Pengaturan beban belajar } \\
\text { 20) Kriteria ketuntasan Minimal (KKM) } \\
\text { 21) Atutan kenaikan kelas } \\
\text { 22) Ketentuan kelulusan } \\
\text { 23) Kalender pendidikan } \\
\text { 24) Lampiran: silabus semua mata pelajaran } \\
\text { Kesesuaian Antarkomponen } \\
\text { 3) Antarkomponen konsisten/logis } \\
\text { 4) Memenuhi ketentuan yang ada }\end{array}$ \\
\hline & $\begin{array}{l}\text { c. Menyem } \\
\text { purnakan } \\
\text { dokumen RPP }\end{array}$ & $\begin{array}{l}\text { 4) Kesesuaian antara SK, KD, Tujuan dan Indikator } \\
\text { 5) Kesesuaian antara indikator dengan soal } \\
\text { 6) Kesesuaian antara materi, media, metode }\end{array}$ \\
\hline Behavior & $\begin{array}{l}\text { Outcomes } \\
\text { (Penerapan hasil } \\
\text { pelatihan di tempat } \\
\text { kerja) }\end{array}$ & $\begin{array}{l}\text { 5) Perangkat pembelajaran guru lengkap } \\
\text { 6) Perangkat pembelajaran guru berkualitas } \\
\text { 7) Pelaksanaan pembelajaran sesuai RPP yang disiapkan } \\
\text { 8) Pembelajaran efektif }\end{array}$ \\
\hline Results & $\begin{array}{l}\text { Impact (Dampak } \\
\text { pelatihan bagi } \\
\text { kualitas } \\
\text { pembelajaran) }\end{array}$ & $\begin{array}{l}\text { 3) Keaktifan belajar siswa meningkat } \\
\text { 4) Ketuntasan belajar siswa tinggi }\end{array}$ \\
\hline
\end{tabular}

Tabel 3. Klasifikasi Tingkat Relevansi \& Efektivitas

\begin{tabular}{clc}
\hline RENTANG & \multicolumn{1}{c}{ KATEGORI } & KODE \\
\hline $91-100$ & Excellent/Baik Sekali & $\mathrm{A}$ \\
\hline $76-90$ & Good/Baik & $\mathrm{B}$ \\
\hline $61-75$ & Average/Cukup & $\mathrm{C}$ \\
\hline $51-60$ & Poor/Kurang & $\mathrm{D}$ \\
\hline$<51$ & Very Poor/Sangat Kurang & $\mathrm{E}$ \\
\hline
\end{tabular}

Tabel 4. Klasifikasi Penguasaan Kompetensi

\begin{tabular}{ccc}
\hline PENGUASAAN KOMPETENSI & KATEGORI & KODE \\
\hline $91-100$ & Amat Baik & A \\
\hline $76-90$ & Baik & B \\
\hline $61-75$ & Cukup & C \\
\hline $51-60$ & Sedang & D \\
\hline$<51$ & Kurang & E \\
\hline
\end{tabular}

Tabel 5. Klasifikasi Penerapan Hasil Diklat di Tempat Tugas

\begin{tabular}{clr}
\hline Nilai Penerapan & Kategori & Kode \\
\hline $91-100$ & Amat Baik & $\mathrm{A}$ \\
\hline $76-90$ & Baik & $\mathrm{B}$ \\
\hline $61-75$ & Cukup & $\mathrm{C}$ \\
\hline $51-60$ & Sedang & $\mathrm{D}$ \\
\hline$<51$ & Kurang & $\mathrm{E}$ \\
\hline
\end{tabular}


Tabel 6. Data Hasil Evaluasi Level Reactions

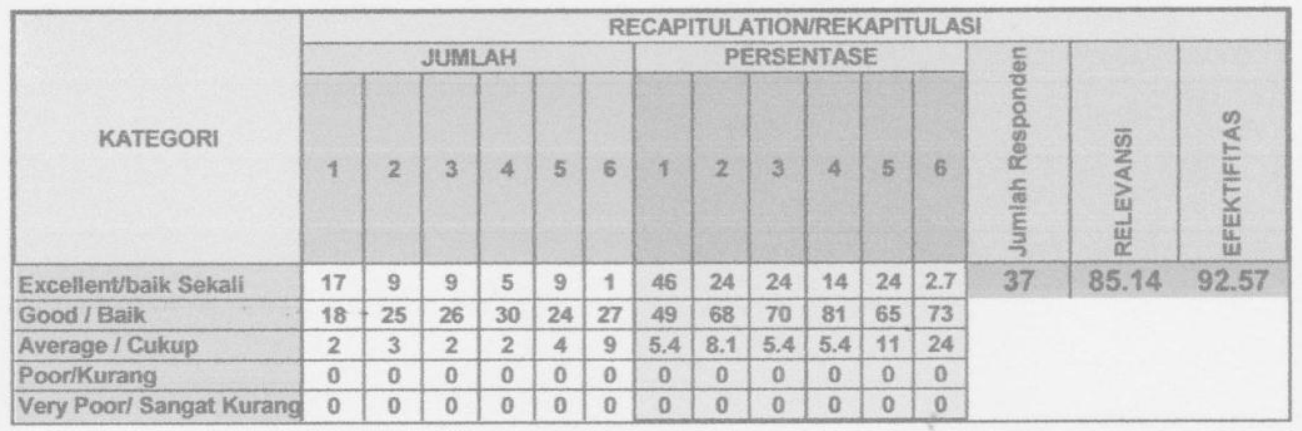

Tabel 7. Analisis Efektivitas In Service Learning 1

\begin{tabular}{lccc}
\hline & All $(\mathrm{n}=35)$ & Male $(\mathrm{n}=9)$ & Female $(\mathrm{n}=26)$ \\
\hline Mean for Pre-Test & 40,92 & 41,39 & 40,05 \\
\hline $\begin{array}{l}\text { Standard Deviation for } \\
\text { Pre-Test }\end{array}$ & 12,86 & 13,61 & 11,798 \\
\hline Mean for Post Test & 67,64 & 68,957 & 64,879 \\
\hline $\begin{array}{l}\text { Standard Deviation for } \\
\text { Post-Test }\end{array}$ & 12,86 & 6,84 & 4,492 \\
\hline Ttest & $3,62583 \mathrm{E}-13$ & $4,22857 \mathrm{E}-09$ & $5,57235 \mathrm{E}-05$ \\
\hline Effect Size & 2,08 & 2,024 & 2,104 \\
\hline
\end{tabular}

Tabel 8. Analisis Efektivitas In Service Learning 2

\begin{tabular}{lccc}
\hline & All $(\mathrm{n}=35)$ & Male $(\mathrm{n}=9)$ & Female $(\mathrm{n}=26)$ \\
\hline Mean for Pre-Test & 43,22 & 41,11 & 50,47 \\
\hline $\begin{array}{l}\text { Standard Deviation for } \\
\text { Pre-Test }\end{array}$ & 12,39 & 10,70 & 15,80 \\
\hline Mean for Post Test & 69,09 & 67,69 & 74,28 \\
\hline $\begin{array}{l}\text { Standard Deviation for } \\
\text { Post-Test }\end{array}$ & 12,39 & 9,08 & 8,75 \\
\hline Ttest & $7,8021 \mathrm{E}-11$ & $4,1547 \mathrm{E}-11$ & 0,06621561 \\
\hline Effect Size & 2,0864 & 2,482 & 1,5066 \\
\hline
\end{tabular}

\section{KESIMPULAN}

1. Program pelatihan pendampingan kepala sekolah oleh pengawas sekolah/madrasah di Palangkaraya memiliki tingkat relevansi sebesar $85,14 \%$ (kategori baik).

2. Program pelatihan pendampingan kepala sekolah oleh pengawas sekolah/madrasah di Palangkaraya memiliki tingkat efektivitas sebesar 92,57\% (kategori baik sekali). Dari
3. hasil pretest dan posttest efektivitas In Service Learning 1 dan 2, secara rata-rata dapat dikatakan bahwa pelaksanaan pelatihan sangat efektif, terbukti dengan rata-rata effect size sebesar 2,0832 termasuk kategori besar karena lebih besar dari 0,8

4. Program pendampingan kepala sekolah oleh pengawas sekolah/madrasah di Palangkaraya berdampak positif terhadap: (a) Implementasi pengelolaan kurikulum sekolah (KTSP) 
dengan skor rata-rata 84,13 (kategori baik), (b) Implementasi persiapan pembelajaran, pelaksanaan pembelajaran dan hasil belajar dengan skor rata-rata 82,91 (Kategori baik). Sehingga dampak secara keseluruhan dengan rata-rata sebesar 83,52 (kategori baik).

\section{DAFTAR PUSTAKA}

Ade Rustiana. Efektivitas Pelatihan Bagi Peningkatan Kinerja Karyawan. (Fakultas Ekonomi, Universitas Negeri Semarang, Semarang, 2010)

Afsar, Bilal, Asad Shahjehan, and Zia Ur Rehman. 2010. "Leader's Influences On Training Effectiveness." Annales Universitatis Apulensis : Series Oeconomica 12 (2): 597-607.

http://search.proquest.com/docview/8562 08500? accountid=37909.

Astridya Paramita dan dan Lusi Kristiana. Focus Group Discussion Tehnique in Qualitative Research. Buletin Penelitian Sistem Kesehatan - Vol. 16 No. 2 April 2013: 117-118 (diunduh tanggal 16 Maret 2016)

Datty, Regina dkk. Evaluasi Efektifitas Program Pelatihan "Know Your Kostumer and Money Laundering" di Bank XYZ Bandung. (Journal Management and Business Review, Volume VI, tahun 2009)

Dhita Ayu Meitaningrum. Efektivitas Pendidikan dan Pelatihan dalam Meningkatkan Kinerja Pegawai. (Universitas Brawijaya, Malang, Jurnal Administrasi Publik (JAP), Vol 1, No.3, tahun 2013

Febrianti M., Eka S., Aribowo S.P., Pengembangan SDM dan Program Diklat untuk Meningkatkan Kualitas Karyawan. (Solo, UNESA, 2015). http://journal.unnes.ac.id/nju/index.php/jd $\mathrm{m}$

Kaswan. Pelatihan dan Pengembangan. (Bandung: Alfabeta, 2011)
Kirkpatrick Donald. L. \& Kirkpatrick James D. Implementing The Four Level's A Practical Guide for Effective Evaluationof Training Program. (San Francisco, California: Berrett-Koehler Publisher, Inc, 2007).

Kirkpatrick, D. L. Evaluating Training Programs: The Four Levels. (San Francisco: BerrettKoehler Publisher, Inc, 1998).

Kirkpatrick, D. L. Evaluating Training Programs: The Four Levels. (San Francisco: BerrettKoehler Publisher, Inc, 1998).

Masadad. Pengaruh Efektivitas Pendidikan Dan Pelatihan Fungsional Terhadap Kinerja Pegawai Pada KantorKementerian Agama Kota Kediri. (Jurnal IImu Manajemen, REVITALISASI, Vol. 1, Nomor 2, September 2012)

Noe, Raymond. Employee Training \& Development. (McGraw-Hill. International Edition, 1998).

Regina Detty. Evaluasi Keefektifan Program Pelatihan "Know Your Customer \& Money Laundering" Di Bank X Bandung. (Makasar: National Conference on Management Research 2008).

Said, M (2014). Continuity and Change of Indonesian Islamic Educational Institution. Asian Social Science; Vol. 10, No. 6; pp. 70-81

Said, M. (2015). Entreprenership Education and the Spirit of Entreprenership of the Students in Indonesia. International Journal of Sustainable Development. Vol.3 No., pp 1569-1582.

Suharsimi Arikunto dan Safrudin Abdul Jabar. Evaluasi Program Pendidikan, Pedoman Teoretis Praktis bagi Mahasiswa dan Praktisi Pendidikan, (Jakarta: Bumi Aksara, 2010) 